\title{
A REVIEW OF FINTECH REGULATIONS IN EMERGING ECONOMIES COUNTRIES - CHINA, SINGAPORE AND HONG KONG
}

\author{
Chee Yuen Yew \\ Honors Student \\ Coventry University \\ PSB Singapore campus
}

\author{
Ameen Talib \\ Head, Applied Projects \\ Business School, Singapore University of Social \\ Science, Singapore \\ ameentalib@suss.edu.sg
}

\begin{abstract}
The world has transformed from traditional business model into digitalised business model, financial services as well. As financial sector is strictly regulated by worldwide regulator in the past, there's the dilemma on the regulation in the combination of Financial Technology ("Fintech"). This paper has selected three samples of emerging countries in Asia to examine the current regulations development. In the end of the paper, there is a comparison of regulatory framework between the samples of countries in order to have more understanding on how the regulator had been working on the Fintech industry to overcome the uncertainty.
\end{abstract}

\section{Keywords-Fintech, Regulations, China, Singapore, Hong Kong}

\section{INTRODUCTION}

"Banking service is necessary, but not banks.” Bill gates

The world economy has been transforming from traditional banking to digital ecosystem. Internet based services have become the most powerful distribution channel tools for businesses environment as well as changing of consumer behaviour nowadays. Following with rapid development in technology and application around the world, there are more opportunities created for businesses. There are many empirical studies on how does internet has changed the business environment and customer's behaviour (Elena-Iulia,
2014; Glova, et al., 2014; Muzellec, et al., 2015).[1][2] Majority of world's retail banks dominating the financial landscape through providing deposit, payment and credit services, however, they are no longer the only players in the industries. In the recent year, there are increasing of alternative finance gains tractions with customers. Nowadays, the financial services required convenience, fast and data collation. Fintech is the combination of "financial" and "technology". The raising of Fintech companies, who are coming into the industries through internet-based services such as online funding, lending service, online payment systems, asset management as well as new money capabilities e.g. Bitcoin and block chain technology. However, how would financial institutions look into this disruption? Banks are enjoyed the high degree of trust from public before the financial crisis happened in year 2008. Although the trust isn't being eliminated but certainly eroded after the post crisis. Although Fintech definitely will disrupt the financial sectors in next several years but the world's banks are the one have an early adoption to transform their business activities. For an instance, Automated Teller Machine ("ATM") and online banking services. According to the research carried out from the Millennial Disruption Index, there are $71 \%$ of respondents would rather go to the dental than listen what's the banker says while there is $73 \%$ are exciting on what kinds of financial services could be delivered from Google, Apple and Amazon (Millennial Disruption Index, 2013).[3] 


\section{Collaboration or Competition}

For decades, traditional banking service are competing with other competitor bank among the industry but the banks have to compete with technology based Fintech companies nowadays. In view of early disruptive Fintech companies around the world such as Alibaba Group \& Tencent, Paypal, M-PESA etc., the communities such as government, investors, entrepreneurs and consumers around the world started to grant attention to the Fintech services. Moreover, there is reported the global investment in Fintech companies raised to USD3.2 billion in the first quarter year 2017 across 260 deals (KPMG International Cooperative, 2017).[4] Here's come with the question with collaboration or competition? While the developing countries has lack of chances deal with financial services, the only way to get them into financial inclusion is the infrastructures. There are believes in Fintech solutions could generate more options than banking options for poor infrastructures developing countries such as India and Pakistan (Kendall, 2017).[5] On the other hand, McKinsey (2016) also pointed that the offers from Fintech such as low cost driver and innovative uses of data could be a threaten to the banks' revenues. From the above examples shown that the collaboration between banks and Fintech companies is better off as banking sector could easier get customer acquisition with collaborate with the advanced technology offering from Fintech companies. There's no doubt on the traditional financial services are moving into digital era, banks and Fintech companies believe that financial technology is not only able to provide products opportunities growth but also build a new architecture which are faster, efficient and more secured across border to another country.[6] In the report of World Payment Report (2016), the volume of global non-cash transaction have accelerated and growth by $10.1 \%$ which up to USD426.3 billion in year 2015.[7] Therefore, Fintech companies seized the opportunities by reaching their customers more easily and less initiative costs during engaging on mobile technology (Kiem, et al., 2016). Despite Fintech provided an exciting landscape to the community, however, there are challenges on whether Fintech's products are fail to be trusted, fail to be secured or fail to comply to local regulatory framework.

According to the survey of White \& Case Fintech M\&A 2016, there are 59\% do not think that Fintech subject to tighter regulations as this may stifle new innovative ideas (Kiem et al., 2016). In order to maintain financial and economy stability, financial sectors are well regulated by worldwide regulator (domestic and international regulator). In the existing regulatory frameworks are not structured and incompetent to supervise the rapid growth in Fintech industries, stated by Kiem et al. (2016).[8] The government's support is the key growth in Fintech industry which are contributing by the entry barriers, funding, infrastructure and regulatory support. In the US, there is complex regulator and state-level structure to oversee the financial services provider, hence created entry barrier to Fintech companies where UK has more friendly regulation to welcome Fintech start-up (Desai, 2015).[9] As Fintech promises to provide better customer experience, the Fintech companies must consider on how to use the regulation for advantage their further growth and development. Therefore, the regulatory have crucial responsibility to ensure the customers are protected. For an instance of international body, New York's Financial Stability Board ("FSB") has been requested from national authorities to assess a supervisory and regulation framework on the cyber risk issue of Fintech from financial stability perspective such as concern on the security of customer's database being available to Fintech third party companies (Financial Sxtability Board, 2017). On the other hand, there is no clear declaration from deposit insurance scheme if customers are refundable when hijacked by third party Fintech companies. Moreover, there are investment risk caused the lack of investor's confident while there are case studies on fallen of POWA TAG, a UK mobile payments companies as well as a high profile crowd funding company, ZANO (Cellan Jones, 2016a; Cellan-Jones, 2016b).[10][11] Furthermore, different regulatory approaches across jurisdictions are also the challenges in Fintech. However, this may not be able to achieve due the existence of Cyber threats and Cyber risk. Therefore, the world financial service regulators such as United States and United Kingdom getting more involving as Cyber risk is the threat 
to financial operating activities (Deloitte \& Touche LLP, 2016).[12] In the report, they also highlighted the cultures of Fintech companies are distinctly different from financial institutions. For example, regulators are more concerning on risk management framework and would prefer banks to maintain their relationship with their customers, hence transform more slowly while comparing to Fintech companies which operate their business in rapid growth of innovation. On the other hand, "big data analysis" is also the one of the new technology paradigm in Fintech industry. There are some of the studies revealed the challenges and technical issues on how big data could accelerates the developments of Fintech industries in near future (In, 2017).

In the section below, the recent developments of Fintech regulation will be conducted by selecting three countries who initiated in Fintech investment and regulations: China, Hong Kong and Singapore.

\section{CHINA}

China, is the home of operating mobile payment and global Fintech services leader by recorded USD1.8 trillion in internet finance sector of the market size of country in year 2015 (McKinsey \& Company, 2016).[13] Among the internet finance, third party payment ("TPP") is one of the wellknown Fintech development in China, which also the core transformation of China's e-commerce industries (Miao \& Jayakar, 2016). According to EY survey report (2016), there are several factors contributing to disintermediation in China with the raising of digital connectivity. In an instance of Alibaba Group, which affiliated with Ant Financial and Tencent becomes global leader in Fintech industries with their TPP in e-commerce business. As a global Fintech player in the world, the central bank People's Bank of China ("PBC") has set up Fintech committee to study the impacts of financial technology on monetary policy, stability and clearing mechanisms in order to seek ways to mitigate the risks (Angier, 2017).[14]

In the past, the financial services industries in China is highly state ownership and controls which had been nationalised under regulation of PBC (Yongwoon \& Dong-Hee, 2016). There are several largest Chinese Bank presence in China such as the Bank of China ("BOC"), the China Construction Bank ("CCB"), the Agricultural Bank of China ("ABC"), and the Industrial and Commercial Bank of China ("ICBC") owned by Chinese central government, which carry commercial banking operation (Kumaravadivel, 2013). Nonetheless, the abovementioned China's banks are heavily regulated by the China Banking Regulatory Commission ("CBRC"), which established in 2003 and took over supervisory and regulatory framework from PBC.

In China's e-commerce service industries, Elinor and Xia (2011) stated that there are five regulator departments presence to oversee and focus on the growth of e-commerce industries which including PBC, the Ministry of Commerce ("MOFCOM"), the State Administration of Industry \& Commerce ("SAIC"), the Ministry of Industry and Information Technology ("MIIT"), and the State Administration of Taxation ("SAT").

According to Yongwoon and Dong-Hee (2016), most of the Fintech companies which providing in TPP are un-regulated before year 2010. Therefore, the Chinese government, PBC established a new regulation on granting payment license for those non-financial institutions (Fintech companies) to operate on TPP services (TransAsia Lawyers, 2010). Under the new government regulatory regime published, PBC had brought 27 Fintech companies, which included Alibaba Group officially legalised on the TPP payment services through granted license.[15]

Subsequently, Alibaba Group extended its finance business to Small-Medium Enterprise ("SME") lending segment through collaborate with financial institutions in China (Meng Jing, 2014).[16] Moreover, the risen of mobile phone payment increasing rapidly also boost the China's ecommerce business, which benefit TPP providers. However, the rapid growth of Fintech businesses in China caused the dilemma of banks (Yongwoon \& Dong-Hee, 2016). In year 2014, the Fintech industry in China is no longer restricted in TPP and mobile payment services, which reform the financial industries in China by allowing Fintech companies to set up private banking services such as investment platform by Tescent and fund lending 
services (Yongwoon \& Dong-Hee, 2016). As such, the Fintech companies grow strong and rapidly through government's supporting in the field innovations.

In the aggressive growth pace of China's Fintech industries, the regulator has established a series of regulatory framework to restrict the online services to maintain financial stability and country growth. For example, PBC and CBRC will be regulating online lending fund depository business; Equitybased crowdfunding and sales of financial products will go under regulation of the China Securities Regulatory Commission ("CSRC"); and online insurance will be going under regulation of the China Insurance Regulatory Commission ("CIRC") (Han Kun Law Offices, 2015).[17] Under the Guiding Opinions on Promoting the Healthy Development of Internet Finance ("the regulation"), China regulatory created a more focus regulatory approach transparency since year 2015 (Jiamin, 2015).

In China, there are financial inclusions through internet based services as aforementioned. Due to Fintech services booming in China in the recent several years, the regulator has endeavoured the potential risks in the disruptors. The authorities in China have established a series of guideline in order to promoting healthy development of internet finance (Jiamin, 2015).[18] Under the new regulation, all the non-bank account would be required to use real name for registration in order to classify the services provider according to security levels (Barbara, 2015).[19] Moreover, the online payment limited the amount in range of RMB1,000 to RMB200,000 in a year. Meanwhile, the regulations don't apply to those transactions which make through banking online payment platforms as banking sector in China is strictly guided by the authorities (The State Council - The People's Republic of China, 2015).[20] The new regulation issued in online payment mainly for avoid the large amounts of fund transfer to third party account as beyond of insurance deposit scheme if any fraud as well as to comply with Anti Money Laundering framework.

As China differentiated with rural and urban are in the country, most of the rural areas have difficulties to have financial inclusion and hence lack of chances to contact with traditional financial services. P2P always linked to one term of financial awareness called as "Shadow Banking". In year 2013, there are survey report on $65 \%$ respondents agreed on the "Shadow Banking" would generate another crisis in China (Caixin Survey, 2013).[21] In an instance of high profile scandal of internet lender Ezubo alleged defrauded USD7.6 million from 900,000 peoples, which exposed the biggest Ponzi scheme (Bloomberg, 2016).[22] On the other hand, there is reported of 1,263 out of 3,853 Chinese P2P lenders were having financial difficulties and 266 P2P lender fled away in year 2015 (The Economist, 2016).[23] As such, Chinese government has finalised a series of rules and regulation to tighten the $\mathrm{P} 2 \mathrm{P}$ lending platform in year 2016. Shen Wei (2015) conducted an investigation on potential risk in China's P2P lending platform and suggested options to regulator to tackle the issues in earlier year.[24] After the P2P tighten regulation been released on 24 August 2016, there are expected more than 2,400 lending platform has been which doesn't comply with new regulations (Reuters, 2016). Under the new rules, the regulator seems turning $\mathrm{P} 2 \mathrm{P}$ into supplement of banking industries where risk compliance applies (Weinland, Don;, 2017). For an instance, P2P companies are restricted to sell management products and issue asset-backed security. Also, those Fintech companies who providing P2P services will be limiting to have third party custodian to manage the funds (Reuters, 2016).[25] In order to ensure the P2P lending platform in China remain transparency, the Chinese government also set up the National Internet Finance Association, which run by PBOC to oversee the risk in sector as well as supervise Fintech companies in China (QuanLin, 2016).[26] Among the new regulations imposed, there are credit limits cap on individual of RMB200,000 and RMB1,000,000 on lending companies (Lockett, 2017).[27] In the result of new regulation applied, there is reported the $\mathrm{P} 2 \mathrm{P}$ growth rate in China slows amid which consequence nearly half dropped in the transaction in year 2016 (Xueqing, 2017).[28] Nonetheless, there are still the risk exists despite the new regulations imposed such as no capital requirement to start up the lending services and do not need to be licensed (China Banking Regulatory Commission, 2017).[29] "The P2P business are not 
strictly regulated, but the regulator is taking step forward," Xu Hongwei says (Bloomberg, 2016). Equity crowdfunding is referring to a financing method which raise fund from public to offer equity as investment thorough internet technology. Belleframme et al. (2015) described the types of crowdfunding platform in the sectors and the challenges. On the other hand, there are potential risks involved money laundering and fraud etc.[30] (Shen Wei, 2015). In an instance of Ezubao case study as aforementioned. Therefore, the Chinese regulator came up regulations to tackle the issues. For examples, a qualified individual investor must able to meet one of the following criteria: invest at least RMB1 million in a single project; obtaining net assets of RMB10 million or RMB3 million net worth with average annual income of RMB500, 000 over the past 3 years (Andrew, 2015).[31] Moreover, there are also the regulations on the requirements of setting up crowdfunding platform and the platform doesn't allow offering P2P lending services at the same time. Meanwhile, the sales of financial products through online, there is no any specific regulation but Chinese government encouraged the collaboration between banks and Fintech companies to deliver their services to customers (Nicholas, 2015).[32] In order to tackle the possible illegal activity, the Chinese regulatory are still working on specific regulatory which believe there are more specific requirement to be published soon (Erdenebileg, 2016).[33]

Although China's financial services heavily regulated by multiple of Chinese regulator, but there are still lack of specific supervision and guideline in coordinate scheme. In China, MIIT and CIRC are in charge of supervision and regulatory work of online insurance. Following by the rapid growth of online platform such as offering financial products and online insurance, CIRC has issued an interim measure in supervisory of online insurance business (Martin, 2015).[34] Under the interim measure report, the insurance institutions may not need to have physical presence but have to fulfil the insurance service requirement (Middle East Insurance Review, 2015).[35] Furthermore, the insurance products also have been limited to offer to public through online insurance business. However, the existing regulation doesn't have any development since
2015 but China is looking forward to step out for more regulation on Insurtech in near future.

\section{HONG KONG}

Hong Kong has the honour of leading financial centres with its unique location in the heart of Asia Pacific region. Although Singapore have been widely recognised as leading premier Fintech hub in Asia currently but Hong Kong has confident to catch up the progress (Bermingham, 2017).[36] In past several years, Hong Kong has been working on Fintech landscape to accelerate the industry in order to become Fintech hub in Asia Pacific region (Barberis, 2014).[37] As China's mainland financial centre, Hong Kong also the largest offshore financial centre, which ideal financial service centre for asset management and capital formation centre. Although there are USD300 million invested in Fintech industries but the regulations are restricted the Fintech innovations (Strait Times, 2016).[38] Indeed, Hong Kong financial services are strictly regulated by the authority, which this explained Hong Kong is world's leading financial centre. However, Hong Kong is urged to focus on establishing their payment technology and cybersecurity in order to compete with its international rivals (Barreto, 2017).[39]

The Hong Kong Monetary Authority ("HKMA") is the central bank in Hong Kong who regulate over the banking sector such as bank and deposit-taking institution (Hong Kong Monetary Authority , 2017).[40] Meanwhile, there are presence of authorities such as the Securities and Futures Commission ("SFC") who regulating over intermediaries dealing in securities, futures and certain investment products (Securities and Futures Commission, 2015).[41] In the insurance sectors, the Office of the Commissioner of Insurance ("OCI") who overseeing the financial conditions and insurance operations, moreover, there also the presence of three self-regulatory institutions who regulate activities of insurance intermediaries (Office of the Commissioner of Insurance, 2013).[42] In data privacy matters regime, which is in charge under regulation of the Office of the Privacy Commissioner ("OPC") where the Communications Authority ("CA") is overseeing the regulation framework of broadcasting and 
telecommunication industries. For those activities involved in money lending must be under supervision and regulation by the Registry of Money Lender.

In order to provide healthy development in Fintech industries and compete with Singapore to promote as Fintech Hub in Asia, the central bank HKMA has established Fintech Facilitation Office ("FFO") in the recent year (Hong Kong Monetary Authority, 2016).[43] Under the main function of FFO, the focus areas are: promote research in Fintech solutions with collaborate with industry; provide a platform to industry communications and interface between Fintech companies and regulators. Subsequently, HKMA launched Fintech Innovation Hub to support the regulatory environment which initiative in regulatory regime, herein called as "Fintech Supervisory Sandbox" (Weiting, 2016).[44] As Fintech growth rapidly in the recent year, therefore there are recent concern raise from the Hong Kong authority

such as distribution ledger technology ("Blockchain"). HKMA believe the new technology

- Blockchain could have potential money laundering potential risk (The Business Times, 2016). As such full of uncertainty in the process of financial innovation, Hong Kong government has been urged to establish Fintech office to better address on issue of regulatory and risk management areas (Zen, 2017).[45]

Following by China has strong presence of digital payment system but not been regulated in past several years, HKMA has established online payment of stored value facilities ("SVF") and retail payment system ("RPS") in year 2014 (Securities and Futures Commission, 2014).[46] The following regime of SVF and RP are amended from consultation paper 2013 (Securities and Futures Commission, 2013).[47] Hong Kong Lawyer (2015) has pointed the consultation paper in year 2013 received the criticism from respondents due to different on competitive advantages between nonbank entities and banking industries and some of requirements issues. However, the new regime has been finalised and followed by a number of respondents. For an instance the well-known smart card payment company, Octopus, who are authorised by HKMA as deposit taking company to operate multi-purpose SVF.[48] Under the new regulation, SVF operator must be able to fulfil the requirements such as licensing, capital requirements, business plan and maximum store value of different SVF (Securities and Futures Commission, 2014). However, for RPS regulation, there are no specific criteria currently as long as there is no impact to the public confidence, financial stability and public confidence day-to-day commercial activities.

Due to lesson learned from global financial crisis in 2008, HKMA has strictly restricted bank and deposit taking companies to approve loan application. As result, there is increasing of nonbank money lender over the year due to easier obtain the mortgage loan from market in borrowers' point of view (HKEXnews, 2013).[49] According to the report, there is approximately HKD30.5 billion of market scale of money lenders and HKD6.6 billion in mortgage market in year 2013. Following by the rapid growth of financial technology, P2P platform could be easier to access the market place by providing lower interest rate. Although the money lenders in Hong Kong are regulated by Companies Registry by license issuing (Companies Registry, 2016),[50] however, there are reported of increasing of illegal loans (Nikki, 2016).[51] According to the Legislative Council (2016),[52] there are the cases on how borrowers are being induced to apply for loan and high fees applies in the process, which is prohibited form current regime. In order to maintain financial stability and health economy in Hong Kong, the Legislative Council urged the government to impose more stringent regulation to restrict $\mathrm{P} 2 \mathrm{P}$ service platforms (Legislative Council, 2017).[53]

The crowdfunding services is considered a new field in Hong Kong. In year 2015, the SFC had issued a notice in relation of crowdfunding (Secrities and Futures Commission, 2014). Under the notices, there are the series of risks and types of crowdfunding are imposed to the existing regulatory regime. Currently, there are no specific regulations on equity crowdfunding and sales of financial products. However, for those companies who want to operate in equity crowdfunding must able to fulfil the requirements under Securities and Futures Ordinance Act and the Companies Winding Up and Miscellaneous Provisions Ordinance Act. In order to better address the crowding issues, the Financial 
Services Development Council has released a proposal on the regulatory framework for equity crowding funding in 2016 (FInancial Services Development Council, 2016).[54] However, the proposal is still under discussion on the execution.

The insurance business in Hong Kong are fall under Insurance Companies Ordinance currently. There was a report of the current authority OCI to be replaced by new regulatory body - Independent Insurance Authority ("AII") to supervise the insurance companies and regulation in Hong Kong (Norton Rose Fulbright, 2010).[55] There is a report shown that wearable devices in Hong Kong, which enabled the insurer able to accumulate information of customers' behaviour (Computer World, 2016).[56] However, there are concerns on the data privacy and technology risks raised when dealing with internet based of insurance services. To overcome such risk, the OCI has issued "Guidance Note on the Use of Internet for Insurance Activities" in year 2001 to minimise the risk exposure (Office of the Commissioner of Insurance, 2001).[57] Under the guideline, the insurance provider must obtain the advanced Internet security technologies.

\section{SINGAPORE}

Singapore, which is a country pushing itself into invention of Fintech industries and aim to be Asian Fintech Hub. The central bank, Monetary Authority of Singapore ("MAS") continued to lead and support Fintech activities in the country among Asia following by Hong Kong (Strait Times, 2016).[58] Singapore has been more aggressive in pursuing Fintech investment over the past two years, however, Singapore faced the immigration law on giving priorities to local Singaporean, which created an obstacle to foreign talents in the Fintech Industries. In an instance of Singaporean complaint on the foreigner taking of their job opportunity in the country, the authority Ministry of Manpower ("MOM") has working in tighten the criteria of foreign employment over the years (Startup Decisions, 2016).[59] Moreover, Singapore as an offshore private financial centre also exposed to the risk from the threaten by multibillion dollars' money laundering scandal from its neighbourhood country as well as tax amnesty to recall the funds from low tax rate countries. In view of Fintech businesses such as Airbnb and Uber etc. growth rapidly over the island, Singapore foresee that uncertainty and risks when Fintech industries are not being regulated.

In Singapore, there are several authorities overseeing and regulating the regime. The major regulators in Singapore of course is the central bank of the country, MAS who supervising financial institutions which including insurance companies, capital markets intermediation, financial markets infrastructure and money lenders. The other regulator involved in Fintech industry such as the

Info-Communications Media Development Authority of Singapore ("IMDA") in charge the regulations of information and communication media sectors and taking over the responsibility of personal data protection after merging of the Infocomm Development Authority of Singapore ("IDA") and the Media Development Authority of Singapore ("MDA") in year 2016 (Strait Times, 2016).

As Singapore aiming to be promoted as Fintech Hub, MAS and National Reserve Foundation ("NRF") has established Fintech office as one-stop service department to serve all the matters related to Fintech (Monetary Authority of Singapore, 2016).[60] Further in the speech of budget 2017, Singapore introduced the "SMEs go digital Programme" in order to strengthen their core business economies to integrate with digital economy (Ministry of Finance, 2017). Under the programme, there are SGD80 million set aside to help the local SMEs to adopt the digital solutions.

Moreover, there is regulatory framework established in recent year to support and encourage the Fintech innovation, the central bank has issued Fintech regulatory sandbox to supervise and ensure the innovative product comply to the financial requirements in year 2016 (Monetary Authority of Singapore, 2017).[61] Under the sandbox regulatory environment, MAS aims the financial innovation products could increase efficiency, manage risk better, open up new opportunities as well as improve lifestyle of Singaporeans (Monetary Authority of Singapore, 2016).[62] To tackle the uncertainty over innovation process yet not to stifle 
the opportunity on testing new technology, MAS allowed the Fintech products supported by more relaxing regulations and compliances. For example, the sandbox entities are provided 6 months to define the experiment is not replicated in the market scale. Upon a series of evaluation requirements, the sandbox entity must fully comply with the relevant regulatory requirements (Monetary Authority of Singapore, 2017).[63] In order to have better experiment space for the Fintech innovative products, Singapore regulatory also emphasises in the framework of enabling the growth and innovation for Fintech companies (Ministry of Finance, 2017).[64]

In most recent, there are reports on MAS collaborated with international financial bodies to come up a series of Fintech landscape. For an instance, MAS collaborated with International Financial Corporation ("IFC") to establish Asean Financial Innovation Network ("Afin") which focus on the standardizing compliance duties, cross border connectivity, increase financial inclusion and remove some inappropriate national restrictions over Fintech industries (Ainger, 2017).[65] Following by the increase of cashless payment linked through advanced digital devices in the past several years, MAS aimed to cashless countries in the future (Hardasmalani, 2016).[66] According to KPMG report (2016)[67], there are several of epayment platforms which promote faster and convenient to the consumers. As Singapore aware that online settlement is the main component in Fintech industries in the future, hence, MAS issued new regulatory on payment framework and established National Payment Council (Monetay Authority of Singapore, 2016).[68] Under the new regulation, MAS able to better envisage and address the issues on e-payment ecosystem regulation such as accessibility, customer data protection and corporate governance. Moreover, the regulatory framework helps the authority to have better understanding on risks and risk management such as cyber security risk, technology risk, moneylaundering and terrorism financing risk. In Singapore, there are also the presence of regulation on SVF (Monetary Authority of Singapore, 2006).[69] For wide accepted SVF such as EZ-Link and NETS, the holders required an approval from MAS if the aggregate amount more than SGD30 million. Despite there are no licensing and capital base requirement as Hong Kong as aforementioned, but the regulatory framework still have restrictions guideline to prevent money laundering.

In Singapore, there are many P2P platforms such as MoolahSense and Validus who lending money to SMEs and investors. The P2P lending platform is strictly regulated by Securities and Futures Act and Financial Advisers Act in Singapore. The lender and borrower subjected to a series of lending and borrowing requirements (Monetary Authority of Singapore, 2016). Moreover, the operator of P2P lending services must obtain Capital Market Services license issue by the central bank. Under the regulation, there is a statement stated that the $\mathrm{P} 2 \mathrm{P}$ lending businesses which used promissory notes to issue to borrower previously need to be licensed for their further lending business services. Under the Fintech activities which involved in money lending is guided by the Moneylender Acts.

Crowdfunding or online crowdfunding platform considered is a new phenomenon in Singapore in recent year. For an instance, the reward based crowdfunding and donation based crowdfunding. In order to support and encourage SMEs business start-up in Singapore, the central bank announced the regulatory framework for security based crowdfunding in 2016 (Monetary Authority of Singapore, 2016).

Under the regulation (essentially are Securities and Futures Act and Financial Advisers Act), the company who wants to offer its shares through crowdfunding platform has required to register with MAS (Monetary Authority of Singapore, 2016). Moreover, there are two ways for SMEs access into equity-crowdfunding platforms. First, the central bank will make this platform rely on current regulatory framework with "small offer" for those SMEs who wish to raise their fund less than SGD5 million within 12 months from retail investors. The another way is accredited institution and investors will be required a base capital requirement to start up their business at least SGD50,000 which reduced from SGD250,000 previously (Monetary Authority of Singapore, 2016). On the other hand, the firm who duel with retail investors have to apply for Capital Market Services license and minimum 
capital of SGD500,000 to set aside before business operation (Yahya,2016).[70]

In Singapore, all the activities which involving in insurance businesses, foreign insurer or insurance intermediaries are subjected to regulate by Insurance Act (Singapore Statues Online, 2015). [71]

For those insurance intermediaries would like to start up their business through internet service based must be able to comply with the Insurance Act and doesn't breach any terms in existing license condition. In order to have better supervision the risk during innovation process and support the online based insurance services, the central bank has urged the insurance intermediaries to avail themselves in Regulatory sandbox (Monetary Authority of Singapore, 2017). For overseas registered insurance provider subjected to seek for

MAS's approval before operating domestic business in Singapore (Monetary Authority of Singapre, 2016). This action had provided the unregistered insurer places the customer at risk.

\section{SUMMARY OF CURRENT REGULATORY FRAMEWORK IN FINTECH}

\begin{tabular}{|c|c|c|c|}
\hline & CHINA & HONG KONG & SINGAPORE \\
\hline $\begin{array}{l}\text { REGUL } \\
\text { ATOR }\end{array}$ & $\begin{array}{l}\text { PBC, } \\
\text { CBRC, } \\
\text { CSRC,CI } \\
\text { RC }\end{array}$ & $\begin{array}{l}\text { HKMA, } \\
\text { SFC, OCI, } \\
\text { OPC, CA, } \\
\text { AII }\end{array}$ & $\begin{array}{l}\text { MAS, } \\
\text { IMDA }\end{array}$ \\
\hline $\begin{array}{l}\text { EPAYM } \\
\text { ENT }\end{array}$ & $\begin{array}{l}\text { License } \\
\text { is } \\
\text { Required }\end{array}$ & $\begin{array}{l}\text { Clearing } \\
\text { and } \\
\text { Settlement } \\
\text { license is } \\
\text { required; } \\
\text { License and } \\
\text { minimum } \\
\text { capital of } \\
\text { HK25 }\end{array}$ & $\begin{array}{l}\text { License is } \\
\text { required for } \\
\text { Payment } \\
\text { and } \\
\text { settlement } \\
\text { regulation; } \\
\text { License and } \\
\text { capital } \\
\text { doesn't }\end{array}$ \\
\hline
\end{tabular}

\begin{tabular}{|c|c|c|c|}
\hline & & $\begin{array}{l}\text { million is } \\
\text { required for } \\
\text { SVF but no } \\
\text { designated } \\
\text { regulation } \\
\text { for RPS }\end{array}$ & $\begin{array}{c}\text { required for } \\
\text { SVF but } \\
\text { subjected to } \\
\text { MAS } \\
\text { approval if } \\
\text { the } \\
\text { aggregate } \\
\text { amount } \\
\text { more than } \\
\text { SGD30 } \\
\text { million }\end{array}$ \\
\hline $\mathbf{P} 2 \mathbf{P}$ & $\begin{array}{c}\text { Online } \\
\text { P2P } \\
\text { lending } \\
\text { platform } \\
\text { required } \\
\text { third } \\
\text { party } \\
\text { financial } \\
\text { institutio } \\
\text { n to } \\
\text { manage } \\
\text { the } \\
\text { funds; } \\
\text { Credit } \\
\text { limits } \\
\text { imposed } \\
\text { RMB200 } \\
\text {,000 for } \\
\text { individua } \\
\text { 1 and } \\
\text { RMB1,0 }\end{array}$ & $\begin{array}{c}\text { Guided by } \\
\text { Current } \\
\text { legislative } \\
\text { SFC } \\
\text { Ordinance, } \\
\text { no specific } \\
\text { regulation } \\
\text { on the field }\end{array}$ & $\begin{array}{c}\text { Capital } \\
\text { Market } \\
\text { license is } \\
\text { required for } \\
\text { P2P lending } \\
\text { platform; } \\
\text { base capital } \\
\text { requirement } \\
\text { for } \\
\text { institutional } \\
\text { investors } \\
\text { reduced to } \\
\text { SGD50,000 } \\
\text { from } \\
\text { SGD250,00 } \\
0 ; \\
\text { institution } \\
\text { who deal } \\
\text { with retail } \\
\text { investor } \\
\text { required }\end{array}$ \\
\hline
\end{tabular}




\begin{tabular}{|c|c|c|c|}
\hline & $\begin{array}{c}\text { 00,000 } \\
\text { For } \\
\text { Lending } \\
\text { Compani } \\
\text { es; No } \\
\text { Capital } \\
\text { Requirem } \\
\text { ents and } \\
\text { License } \\
\text { Registry } \\
\text { From } \\
\text { Local } \\
\text { Authority }\end{array}$ & & $\begin{array}{c}\text { SGD500,00 } \\
0 \text { base } \\
\text { capital }\end{array}$ \\
\hline $\begin{array}{c}\text { Equity } \\
\text { Crowd } \\
\text { funding/ } \\
\text { Sales of } \\
\text { financial } \\
\text { product }\end{array}$ & $\begin{array}{c}\text { No P2P } \\
\text { Lending } \\
\text { Services } \\
\text { to be } \\
\text { Deliver } \\
\text { After } \\
\text { Registere } \\
\text { d for } \\
\text { Equity } \\
\text { Crowdfu } \\
\text { Nding } \\
\text { services; } \\
\text { Remain } \\
\text { Members } \\
\text { hip with } \\
\text { Securitie } \\
\text { S } \\
\text { Associati } \\
\text { on of }\end{array}$ & $\begin{array}{c}\text { License is } \\
\text { required } \\
\text { depending } \\
\text { on the } \\
\text { nature of } \\
\text { activity } \\
\text { under } \\
\text { legislative } \\
\text { SFC } \\
\text { Ordinance } \\
\text { and the } \\
\text { Companies } \\
\text { (Winding } \\
\text { Up and } \\
\text { Miscellaneo } \\
\text { us } \\
\text { Provisions) } \\
\text { Ordinance, } \\
\text { no specific }\end{array}$ & $\begin{array}{l}\text { Categorised } \\
\text { under } \mathrm{P} 2 \mathrm{P} \\
\text { regulations }\end{array}$ \\
\hline
\end{tabular}

\begin{tabular}{|c|c|c|c|}
\hline & $\begin{array}{c}\text { China; } \\
\text { no } \\
\text { specific } \\
\text { regulatio } \\
\text { n on } \\
\text { online } \\
\text { sale of } \\
\text { financial } \\
\text { products }\end{array}$ & $\begin{array}{l}\text { regulation } \\
\text { on the field }\end{array}$ & \\
\hline $\begin{array}{l}\text { Online } \\
\text { Insuran } \\
\text { ce }\end{array}$ & $\begin{array}{c}\text { Insuranc } \\
\text { e license } \\
\text { is } \\
\text { required } \\
\text { for direct } \\
\text { insuranc } \\
\text { e sale; } \\
\text { where } \\
\text { through } \\
\text { third } \\
\text { party } \\
\text { platform, } \\
\text { no } \\
\text { license is } \\
\text { required }\end{array}$ & $\begin{array}{l}\text { Insurance } \\
\text { license is } \\
\text { Required } \\
\text { Under } \\
\text { Insurance } \\
\text { Companies } \\
\text { Ordinance, } \\
\text { no specific } \\
\text { regulation }\end{array}$ & $\begin{array}{l}\text { Insurance } \\
\text { license is } \\
\text { required } \\
\text { and } \\
\text { regulated } \\
\text { under } \\
\text { Insurance } \\
\text { Act }\end{array}$ \\
\hline $\begin{array}{l}\text { OTHER } \\
\text { DEVEL } \\
\text { OPMEN } \\
\text { TS }\end{array}$ & $\begin{array}{c}\text { Looking } \\
\text { forward } \\
\text { on more } \\
\text { regulatio } \\
\text { ns } \\
\text { develop } \\
\text { ments }\end{array}$ & $\begin{array}{c}\text { Fintech } \\
\text { Supervisory } \\
\text { Sandbox }\end{array}$ & $\begin{array}{c}\text { Fintech } \\
\text { Regulatory } \\
\text { Sandbox }\end{array}$ \\
\hline
\end{tabular}




\section{DISCUSSIONS}

An integration of financial and technology have become a popular topic and exciting areas for exploration in the recent year. From the literature review, there are proactive investment made in Fintech industries around the world, according to the report of KPMG (KPMG International Cooperative, 2017). However, the business challenges and issues are still bugging the start-up of the Fintech industries which including the regulatory framework and entry barriers. Due to the world had been changed to digital ecosystem and the changes of business model over the business industries, the regulatory framework have become more challenges as the current legislative is illequipped (Kiem, et al., 2016). The challenges could be more wide range over the uncertainty in Fintech industry such as data privacy protection and cyber security (Shen Wei, 2015). Positively, the regulatory around the world had been working very hard to understanding the risks could be aroused in the industries and findings solutions to mitigate the risks.

A table of regulatory framework comparison between China, Hong Kong and Singapore has been conducted. From the literature review, China is the global Fintech player in the early century but the regulations are too lax (Yongwoon \& Dong-Hee, 2016). In view of China's internet finance activities proactive in year 2014, as well as the high profiled scandal of Ezubo, PBC had been worked with others authorities on the regulation framework in year 2016. Compared to financial leading centre in Hong Kong and Singapore, HKMA and MAS had been working and amending the regulatory framework over the time. In most of the comparison areas, there are different of regulatory approach among the samples countries. For an instance, digital payment services in China required business operating license but no specific regulation SVF; while Hong Kong issued the new SVF regime in year 2014 to prevent money laundering through Multi-purpose SVF (Hong Kong Lawyer;, 2015). Under the regime, license and minimum capital of HKD25 million is required. In Singapore, there are no specific regulations in SVF but the holders subjected to approval if the holder has aggregate sum of SGD30 million.

China has the biggest P2P lending platform and equity crowdfunding compared to Hong Kong and Singapore, according to the report of EY and DBS (Sachin \& Lloyd, 2016). Therefore, China has more specific regulations in term of licensing and minimum capital requirements for business operator. For Hong Kong, there is no specific regulations under $\mathrm{P} 2 \mathrm{P}$ and equity crowdfunding services as this is considered a new phenomenon in the country. For Singapore, the capital market license is required for business operator but the requirements of base capital requirement reduced for institutional investors in order to fostering SMEs start-up. In insurance sector, China required insurance providers must have obtained insurance license but no license is required through if the sales of insurance third party platform. Although there is no specific regulation on overseas registered internet financial services, but Singapore still giving advises to investors who wants to invest through internet platform. For an instance, Singapore warned investors in unregulated platform of binary options trading platform (Nicole, 2017). Going forward, Singapore would have more specific legislative framework for online financial services.

As Hong Kong and Singapore in the competition to become Fintech Hub in Asia, there will be more regulatory framework to be issued in near future. For an instance, the regulatory sandbox published in Hong Kong and Singapore to supervise the innovative process in order to mitigate the risks before enter into large scale market. In the comparison of the regulatory sandbox between Hong Kong and Singapore, the purpose is the same approach to mitigate the possible risks but there are different views in the innovative process. For an instance, HKMA has no intention to relax the possible regulation but MAS do. Moreover, there has no details on HKMA's supervisory sandbox but MAS had given all the details for the application and evaluation process. However, the capital is required for the start-up Fintech activities in the competition of Fintech hub. According to a report conducted by KPMG (2016), Singapore has higher government incentives and funding in Fintech startup compared to Hong Kong. Although Singapore 
has lead in front of Hong Kong currently but Hong Kong has confident to catch up with the trend.

The fact that Fintech industry will be a disruptor for new digital ecosystem. From the literature review, an understanding on how the world has get ready to enter the new ecosystem as well as the challenges may face in the near future. Regulatory has played a crucial role in this new arise industry. From the literature review on regulation of China, Hong Kong and Singapore, there is an understanding on the comparison of the regulation framework as well as the approach in countries. China, being the largest Fintech player expected to have more regulations for the industry. Hong Kong and Singapore, have been racing to be promoted as Asia Fintech Hub. Therefore, the society is eyeing on who will be the winner in near future.

\section{REFERENCE:}

[1] Elena-Iulia, 2014. The impact of the Internet on the business environment. Procedia Economics and Finance, Volume 15, pp. 951-958.

[2] Muzellec, L., Ronteau, S. \& Lamkin, M., 2015. Two-sided Internet platforms: A business model lifecycle perspective. Industrial Marketing Management, Volume 45, pp. 139-150.

[3] Millennial Disruption Index, 2013. The Millennial Disruption Index. [Online]

Available at: http://ritholtz.com/wpcontent/uploads/2015/04/MDI.png

[Accessed 15 May 2017].

[4] KPMG International Cooperative, 2017. Q1'17 edition of KPMG International's Pulse of, s.l.: KPMG International Cooperative.

[5] Kendall, J., 2017. Fintech Companies Could Give Billions of People More Banking Options. [Online] Available at: https://hbr.org/2017/01/fintech-companiescould-give-billions-of-people-more-bankingoptions [Accessed 1 June 2017].

[6] McKinsey \& Company;, 2016. Cutting through the noise around financial technology. [Online] Available at:

http://www.mckinsey.com/industries/financialservices/our-insights/cutting-through-the-noisearound-financial-technology

[Accessed 27 May 2017].

[7] Capgemini \& BNP Paribas, 2016. 2016 World

Payment Report, s.1.: Capgemini and BNP Paribas.
[8] Kiem, R., Potel, G., Trillmich, P. \& Weir, G., 2016. Regulatory and business challenges to fintech $M \& A$. [Online]

Available at:

https://www.whitecase.com/publications/insight/reg ulatory-and-business-challenges-fintech-ma

[Accessed 17 May 2017].

[9] Desai, F., 2015. The Fintech Boom And Bank Innovation. [Online]

Available at:

https://www.forbes.com/sites/falgunidesai/2015/12/ 14/the-fintech-revolution/\#763bf095249d

[Accessed 21 May 2017].

[10] Cellan Jones, R., 2016a. Zano: The rise and fall of Kickstarter's mini-drone. [Online]

Available at:

http://www.bbc.com/news/technology-35356147

[Accessed 16 May 2017].

[11] Cellan-Jones, R., 2016b. Powa: The startup that fell to earth. [Online]

Available at: http://www.bbc.com/news/technology-35860814 [Accessed 16 May 2017].

[12] Deloitte \& Touche LLP, 2016. Navigating the year ahead Banking regulatory outlook 2017, s.1.: Deloitte \& Touche LLP.

[13] McKinsey \& Company, 2016. What's next for China's boomng Fintech sector?. [Online]

Available at:

file:///C:/Users/Yuenyew/Downloads/Whats-nextfor-Chinas-booming-fintech-sector.pdf [Accessed 15 May 2017].

[13] Miao, M. \& Jayakar, K., 2016. Mobile payments in Japan, South Korea and China: Crossborder convergence or divergence of business models?. Telecommuncations Policy, 40(2-3), pp. 182-196.

[14] Angier, N., 2017. China sets up fintech committee at central bank, s.l.: CNBC.

[15] Yongwoon, S. \& Dong-Hee, S., 2016. Analyzing China's Fintech Industry from the Perspective of Actor-Network Theory. Telecommunication Policy, 40(2-3), pp. 168-181

[16] Meng Jing, 2014. Alibaba, lenders team up for SME financing, China: China Daily.

[17] Han Kun Law Offices, 2015. China issues the long-awaited guidelines on Internet finance, s.l.: Lexology.

[18] Jiamin, L., 2015. Guiding Opinions on

Promoting

the Healthy Development of Internet Finance. 
[Online]

Available at:

https://www.mizuhobank.com/service/global/cndb/e conomics/briefing/pdf/R216-0029-XF-0105.pdf [Accessed 18 May 2017].

[19] Barbara, L., 2015. China issues comprehensive regulations on internet finance, s.l.: Norton Rose Fulbright.

[20] The State Council - The People's Republic of China,

2015. China central bank details rules on online payment. [Online]

Available at:

http://english.gov.cn/state_council/ministries/2015/ 12/29/content_281475262666364.htm [Accessed 21 May 2017].

[21] Caixin Survey, 2013. Will shadow banking cause a crisis in China?. [Online] Available at: http://service.caixin.com/pollcode/resulten/batch/57 6 [Accessed 16 May 2017].

[22] Bloomberg, 2016. China Imposes Caps on $P 2 P$

Loans to Curb Shadow-Banking Risks. [Online] Available at:

https://www.bloomberg.com/news/articles/2016$08-$

24/china-imposes-caps-on-p2p-lending-to-curbshadow-banking-risk [Accessed 21 May 2017]. [23] The Economist, 2016. The allure and the peril of Chinese fintech companies. [Online]

Available at:

http://www.economist.com/news/finance-andeconomics/21688940-allure-and-peril-chinesefintech-companies-taking-flight

[Accessed 21 May 2017].

[24] Shen Wei, 2015. Internet lending in China: Status quo, potential risks and regulatory options. Computer Law \& Security Review, 31(6), pp. 793809.

[25] Reuters, 2016. China publishes new rules tightening regulation of peer-to-peer lending.

[Online]

Available at: http://www.reuters.com/article/chinabanks-cbrc-idUSB9N1AS01A

[Accessed 16 May 2017].

[26] QuanLin, Q., 2016. New China Internet

Finance

Association draws 400 members. [Online]

Available at:

http://www.chinadaily.com.cn/china/2016-

03/28/content_24143657.htm

[Accessed 21 May 2017].
[27] Lockett, H., 2017. China P2P industry lending nears Rmbltn despite crackdown, new regulations. [Online] Available at:

https://www.ft.com/content/160e89aa-cbc4-330c8b18-6716378cca3f [Accessed 16 May 2017]. [28] Xueqing, 2017. P2P lending growth slows amid new compliance rules. [Online]

Available at:

http://www.chinadaily.com.cn/business/201701/05/content_27866083.htm

[Accessed 21 May 2017].

[29] China Banking Regulatory Commission, 2017. The CBRC Issued the Guidelines on Online Lending Fund Depository Business. [Online] Available at:

http://www.cbrc.gov.cn/EngdocView.do?docID= D7

\section{DD12CF3C4AB09B14C9F4080604D7}

[Accessed 21 May 2017].

[30] Belleframme, P., Omrani, N. \& Peitz, M., 2015. The economics of crowdfunding platforms. Information Economics and Policy, pp. 11-28.

[31] Andrew, 2015. China: Equity

Crowdfunding Regulations Published.

[Online]

Available at:

http://blog.sharein.com/regulations-allowingchina-share-crowdfunding-revolution-published/ [Accessed 21 May 2017].

[32] Nicholas, 2015. China Sets the Rules for Internet Finance. [Online] Available at: http://www.frbsf.org/banking/asiaprogram/pacific-exchange-blog/china-sets-therules-for-internet-finance/[Accessed 16 May 2017].

[33] Erdenebileg, Z., 2016. Better Together: Assessing the Potential of Crowdfunding in China. [Online] Available at: http://www.chinabriefing.com/news/2016/10/13/crowdfunding-inchina.html [Accessed 15 May 2017].

[34] Martin, T., 2015. Legal News \& Analysis Asia Pacific - China - Insurance \& Reinsurance See more at:

http://www.conventuslaw.com/report/china-newcirc-requirements-for-internet-

[35] Middle East Insurance Review, 2015.

China:New online insurance regulation to take effect from 1 Oct, s.l.: Middle East Insurance Review. 
[36] Bermingham, F., 2017. Can Hong Kong compete with Singapore as fintech hub?. [Online] Available at:

http://www.gtreview.com/news/asia/can-hongkong-compete-with-singapore-as-fintech-hub/ [37] Barberis, J., 2014. The Rise of FinTech Getting Hong Kong to lead the digital financial transition in APAC, Hong Kong: Hong Kong Fintech.

[38] Strait Times, 2016. In race to be Asia's fintech hub, Singapore leads Hong Kong, Singapore: Singapore Press Holdings.

[39] Barreto, E., 2017. Hong Kong should up its fintech game to remain relevant: council, Hong Kong: Reuters.

[40] Hong Kong Monetary Authority, 2017. About the HKMA. [Online] Available at: http://www.hkma.gov.hk/eng/about-thehkma/hkma/about-hkma.shtml

[Accessed 18 May 2017].

[41] Securities and Futures Commission, 2015. Our Role. [Online]

Available at: http://www.sfc.hk/web/EN/about-thesfc/our-role/[Accessed 1 May 2017].

[42] Office of the Commissioner of Insurance, 2013. Regulatory framework. [Online]

Available at:

http://www.oci.gov.hk/framework/index 10.html [Accessed 17 May 2017].

[43] Hong Kong Monetary Authority, 2016. Cooperation Agreement between the Hong Kong Monetary Authority and the Financial Conduct Authority on fintech co-operation. [Online] Available at: http://www.hkma.gov.hk/eng/keyinformation/press-releases/2016/201612076.shtml [Accessed 28 May 2017].

[44] Weiting, L., 2016. HKMA launches fintech innovation hub, China: China Daily Asia.

[45] Zen, S., 2017. FSDC urges Hong Kon g government to set up fintech office, focus on blockchain, China: South China Morning Post.

[46] Securities and Futures Commission, 2014. Consultation Conclusions on the Proposed Amendments to the Professional Investor Regime and Further Consultation on the Client Agreement Requirements, Hong Kong: Securities and Futures Commission.
[47] Securities and Futures Commission, 2013. Consultation Paper on the Proposed Amendments to the Professional Investor Regime and the Client Agreement Requirements, Hong Kong: Securities and Futures Commission. [48] Hongkong Lawyer;, 2015. Hong Kong Concludes Payments Regulation Consultation. [Online] Available at: http://www.hklawyer.org/content/hong-kong-concludespayments-regulation-consultation

[Accessed 21 May 2017].

[49] HKEXnews, 2013. Industry Overview, Hong Kong: HKEXnews.

[50] Companies Registry, 2016. MONEY

LENDERS LICENCE ADDITIONAL

LICENSING CONDITIONS. [Online]

[51] Nikki, S., 2016. Hong Kong government to

impose new rules on money lenders to combat

illegal loans, Hong Kong: South China Morning Post.

[52] Legislative Council, 2016. Regulatory and related arrangements to tackle malpractices by financial intermediaries for money lending, Hong Kong: Legislative Council.

[53] Legislative Council, 2017. Press Release.

[Online] Available at:

http://www.legco.gov.hk/yr16-

17/english/press/pr20170206-1.html [Accessed 16 May 2017].

[54] FInancial Services Development Council, 2016. Introducing a Regulatory Framework for, Hong Kong: FInancial Services Development Council. [55] Norton Rose Fulbright, 2010. A total makeover of the Hong Kong insurance supervisory system?.

[Online] Available at:

http://www.nortonrosefulbright.com/knowledge/pu b

lications/30529/a-total-makeover-of-the-hongkong-

insurance-supervisory-system

[Accessed 2 June 2016].

[56] Computer World, 2016. Hong Kong

consumers owns more than one wearable

devices. [Online] Available at:

http://cw.com.hk/news/hong-kong-consumersowns-more-one-wearable-devices [Accessed 2 June 2017].

[57] Office of the Commissioner of Insurance, 2001. Guidance Note On The Use of Internet for Insurance Activities, Hong Kong: Office of the Commissioner of Insurance. 
[58] Strait Times, 2016. Singapore's media and infocomm authorities IDA and MDA will merge to form IMDA, Singapore: SIngapore Press Holdings. [59] Startup Decisions, 2016. Employment Pass Tightening - Singaporeans First. [Online] Available at:

http://www.startupdecisions.com.sg/blog/employm ent-pass-tightened/

[Accessed 2 June 2017].

[60] Monetary Authority of Singapore, 2016.

Fintech Regulatory Sandbox Guidlines,

Singapore: Monetary Authority of Singapore. [61] Monetary Authority of Singapore, 2017. MAS FinTech Regulatory Sandbox. [Online] Available at: http://www.mas.gov.sg/Singapore-FinancialCentre/Smart-Financial-Centre/FinTechRegulatory-Sandbox.aspx [Accessed 18 May 2017].

[62] Monetary Authority of Singapore, 2016. MAS to Improve Access to Crowd-funding for Start-ups and SMEs. [Online] Available at:

http://www.mas.gov.sg/News-and-

Publications/Media-Releases/2016/MAS-toImprove-Access-to-Crowdfunding-for-Startupsand-SMEs.aspx [Accessed 18 May 2017]. [63]Monetary Authority of Singapore, 2016. New FinTech Office: A One-Stop Platform to Promote Singapore as a FinTech Hub. [Online] Available at: http://www.mas.gov.sg/news-andpublications/media-releases/2016/new-fintechoffice.aspx [Accessed 18 May 2017]. [64] Ministry of Finance, 2017. Budget 2017 - An Innovative and Connected Economy. [Online] Available at:

http://www.singaporebudget.gov.sg/budget_2017/b udgetspeech/pb.aspx

[Accessed 2 June 2017].

[65] Ainger, N., 2017. Monetary Authority of Singapore teams up with World Bank's IFC to encourage Asian fintech innovation, s.l.: CNBC. [66] Hardasmalani, R., 2016. Cashless is king, as MAS maps out e-payment future, Singapore:

TODAY

[67] KPMG, 2016. Singapore Payments

Roadmap, SIngapore: KPMG.

[68] Monetary Authority of Singapre, 2016.

Financial Advisers Act/Financial Advisers

Regulations. [Online]Available at:

http://www.mas.gov.sg/regulations-andfinancial-stability/regulations-guidance-andlicensing/insurance/insurancelicensing/insurance-brokers.aspx
[Accessed 3 June 2017]. [69] Monetary Authority of Singapore, 2006. Stored Value Facility Guidelines. [Online] Available at: http://www.mas.gov.sg/ /media/resource/legislation guidelines/payment_system/payment_act2006/gui delines/Stored\%20Value\%20Facility\%20Guidelines \%20final\%20version.pdf

[Accessed 2 June 2017].

[70] Yahya, Y., 2016. New licensing regime set for crowdfunding platforms, Sngapore: Singapore Press Holdings.

[71] Singapore Statues Online, 2015. Insurance Act Chp 142 [Online] Available at: http://statutes.agc.gov.sg/aol/search/display/view.w 3p;page $=0$; query $=$ DocId\%3A\%223bf026f $8-05 \mathrm{~d} 6-$ 4c03-8df7-

d34478f721a4\%22\%20Status\%3Apublished\%20De pth\%3A0\%20\%20TransactionTime\%3A\%2213\%2 F11\%2F $2015 \% 22 ; \mathrm{rec}=0$

[Accessed 18 May 2017].

[72] Sachin, M. \& Lloyd, J., 2016. The Rise of Fintech In China, s.l.: EY and DBS. 
